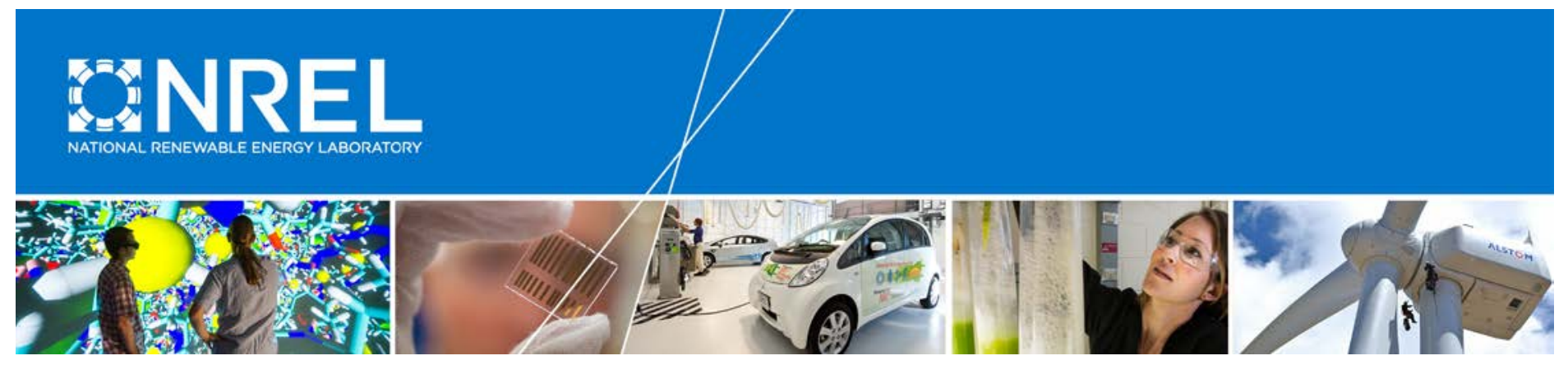

\title{
Analysis of Bright Harvest Remote Analysis for Residential Solar Installations
}

J. Nangle and J. Simon

National Renewable Energy Laboratory

NREL is a national laboratory of the U.S. Department of Energy Office of Energy Efficiency \& Renewable Energy Operated by the Alliance for Sustainable Energy, LLC

This report is available at no cost from the National Renewable Energy Laboratory (NREL) at www.nrel.gov/publications.

Technical Report

NREL/TP-7A40-64470

June 2015

Contract No. DE-AC36-08GO28308 


\title{
Analysis of Bright Harvest Remote Analysis for Residential Solar Installations
}

\author{
J. Nangle and J. Simon \\ National Renewable Energy Laboratory \\ Prepared under Task No. LRCS.NC80
}

NREL is a national laboratory of the U.S. Department of Energy Office of Energy Efficiency \& Renewable Energy Operated by the Alliance for Sustainable Energy, LLC

This report is available at no cost from the National Renewable Energy Laboratory (NREL) at www.nrel.gov/publications.

National Renewable Energy Laboratory 15013 Denver West Parkway

Golden, CO 80401

303-275-3000 • www.nrel.gov

\section{Technical Report}

NREL/TP-7A40-64470

June 2015

Contract No. DE-AC36-08GO28308 


\title{
NOTICE
}

This report was prepared as an account of work sponsored by an agency of the United States government. Neither the United States government nor any agency thereof, nor any of their employees, makes any warranty, express or implied, or assumes any legal liability or responsibility for the accuracy, completeness, or usefulness of any information, apparatus, product, or process disclosed, or represents that its use would not infringe privately owned rights. Reference herein to any specific commercial product, process, or service by trade name, trademark, manufacturer, or otherwise does not necessarily constitute or imply its endorsement, recommendation, or favoring by the United States government or any agency thereof. The views and opinions of authors expressed herein do not necessarily state or reflect those of the United States government or any agency thereof.

This report is available at no cost from the National Renewable Energy Laboratory (NREL) at www.nrel.gov/publications.

Available electronically at SciTech Connect http:/www.osti.gov/scitech

Available for a processing fee to U.S. Department of Energy and its contractors, in paper, from:

\author{
U.S. Department of Energy \\ Office of Scientific and Technical Information \\ P.O. Box 62 \\ Oak Ridge, TN 37831-0062 \\ OSTI http://www.osti.gov \\ Phone: 865.576.8401 \\ Fax: 865.576.5728 \\ Email: reports@osti.gov
}

Available for sale to the public, in paper, from:

\author{
U.S. Department of Commerce \\ National Technical Information Service \\ 5301 Shawnee Road \\ Alexandra, VA 22312 \\ NTIS http://www.ntis.gov \\ Phone: 800.553 .6847 or 703.605 .6000 \\ Fax: 703.605.6900 \\ Email: orders@ntis.gov
}




\section{Acknowledgments}

The authors would like to thank the team at Bright Harvest for the collaborative effort to review, analyze and improve the remote assessment of residential solar sites. In addition, the authors appreciate the support of the NREL Commercialization Assistance Program (NCAP) for providing resources that enabled NREL staff time in support of Bright Harvest. 


\section{Nomenclature or List of Acronyms}

CI

NREL

PV

SAV
Confidence Interval

National Renewable Energy Laboratory

Photovoltaic

Solar Access Value 


\section{Introduction}

Bright Harvest provides remote shading analysis and design products for residential PV system installers. An image of a remotely generated 3D model of a residence is provided in the image below.

The National Renewable Energy Laboratory (NREL) through the NREL Commercialization Assistance Program, completed comparative assessments between on-site measurements and remotely calculated values to validate the accuracy of Bright Harvest's remote shading and power generation estimating algorithms.

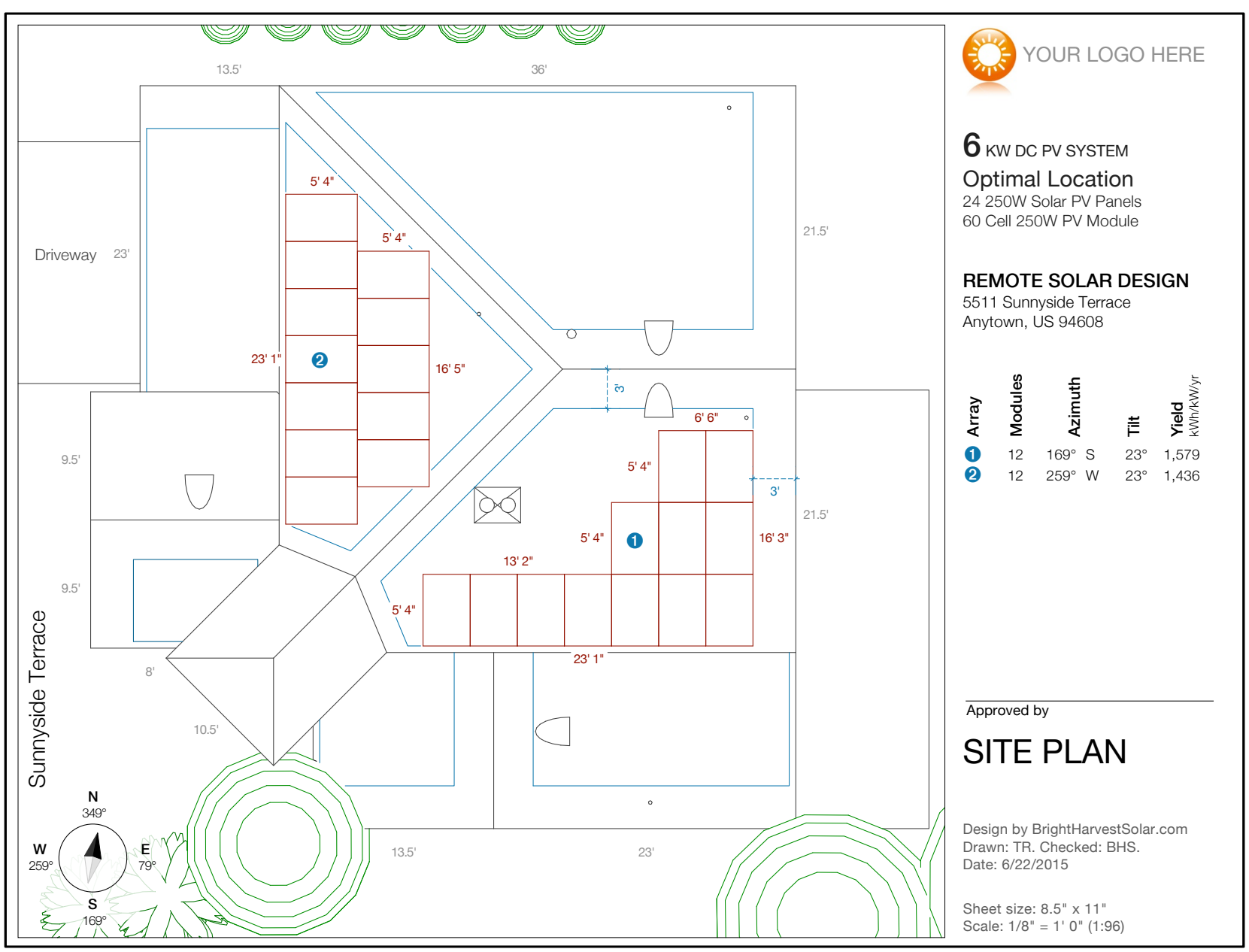

Figure 1: Bright Harvest Example Site Plan 


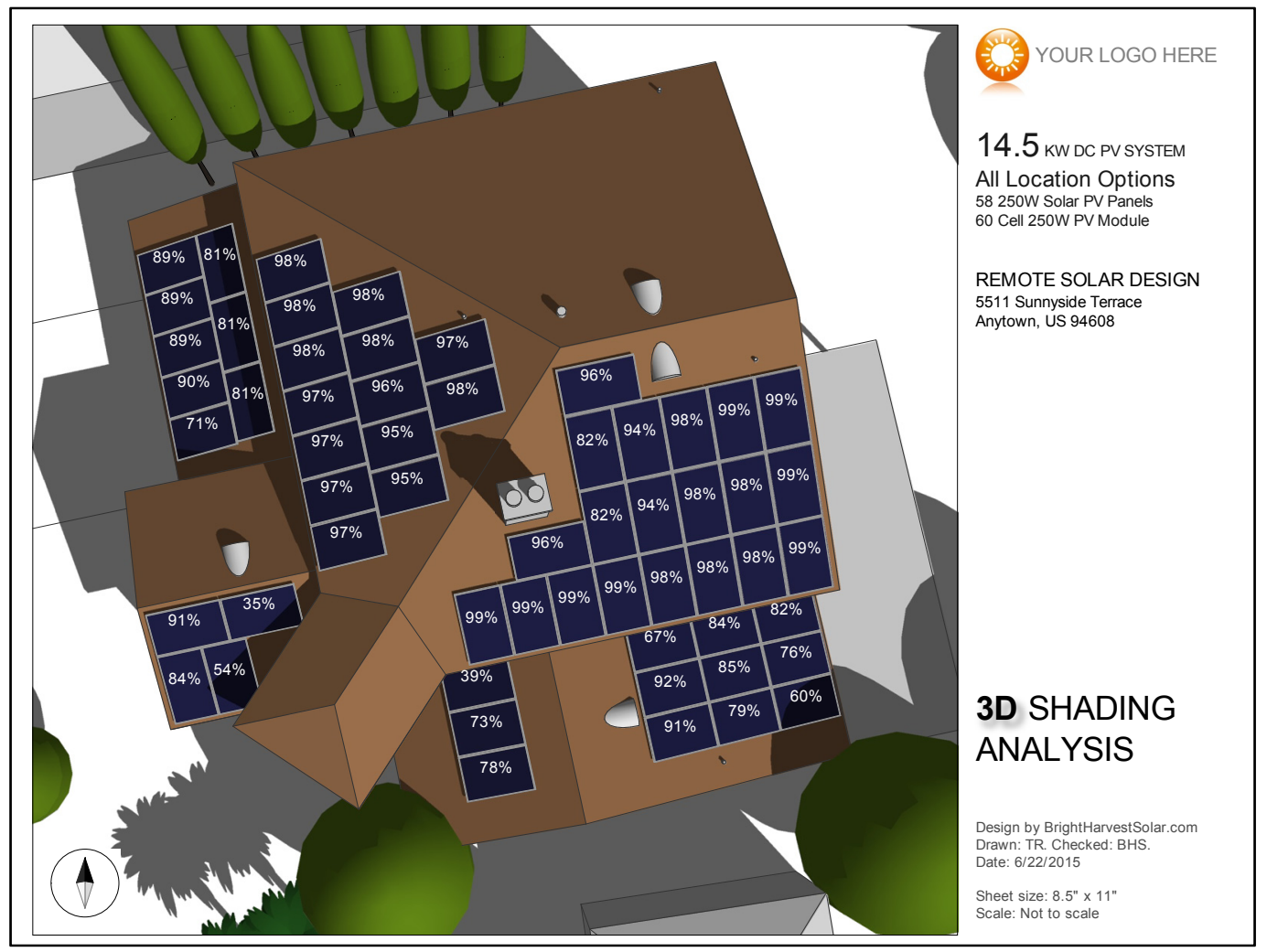

Figure 1: Bright Harvest Example 3D Shading Analysis

\begin{tabular}{|c|c|c|c|c|c|c|c|c|c|c|}
\hline \multicolumn{10}{|c|}{ SHADING ANALYSIS } & \multirow{8}{*}{$\begin{array}{l}\mathbf{1 4 . 5} \text { kW DC PV SYSTEM } \\
\text { All Location Options } \\
58 \text { 250W Solar PV Panels } \\
60 \text { Cell 250W PV Module }\end{array}$} \\
\hline ARRAY & (1) & (2) & \multicolumn{2}{|c|}{ (3) } & 4 & 6 & 6 & ALL & $\mathrm{kWh}$ & \\
\hline January & 97 & 97 & \multicolumn{2}{|c|}{81} & 79 & 67 & 67 & $87 \%$ & 1,240 & \\
\hline February & 97 & 96 & \multicolumn{2}{|c|}{78} & 71 & 70 & 68 & $87 \%$ & 1,076 & \\
\hline March & 96 & 97 & \multirow{2}{*}{\multicolumn{2}{|c|}{$\begin{array}{l}80 \\
88\end{array}$}} & 62 & 82 & 65 & $88 \%$ & 1,683 & \\
\hline April & 95 & 98 & & & 59 & 87 & 66 & $90 \%$ & 1,786 & \\
\hline May & 95 & 97 & \multicolumn{2}{|c|}{85} & 58 & 83 & 63 & $88 \%$ & 1,967 & \\
\hline June & 96 & 98 & \multicolumn{2}{|c|}{85} & 59 & 80 & 64 & $88 \%$ & 2,017 & \\
\hline July & 95 & 98 & \multicolumn{2}{|c|}{85} & 58 & 82 & 65 & $88 \%$ & 2,052 & \multirow{10}{*}{$\begin{array}{l}\text { REMOTE SOLAR DESIGN } \\
5511 \text { Sunnyside Terrace } \\
\text { Anytown, US } 94608\end{array}$} \\
\hline August & 95 & 98 & & & 59 & 89 & 65 & $89 \%$ & 1,997 & \\
\hline September & 96 & 98 & & & 57 & 83 & 67 & $89 \%$ & 1,745 & \\
\hline October & 98 & 97 & & & 75 & 73 & 71 & $88 \%$ & 1,359 & \\
\hline November & 97 & 96 & & & 75 & 67 & 67 & $87 \%$ & 1,238 & \\
\hline December & 98 & 95 & & & 74 & 63 & 66 & $86 \%$ & 1,164 & \\
\hline Summer & 96 & 98 & & & 60 & 82 & 65 & $89 \%$ & 11,136 & \\
\hline \multicolumn{10}{|l|}{ Annual } & \\
\hline SAV & 96 & 97 & \multicolumn{2}{|c|}{84} & 64 & 80 & 66 & $88 \%$ & \multirow[t]{2}{*}{19,322} & \\
\hline TSRF & 95 & 86 & & & 56 & 62 & 65 & $81 \%$ & & \\
\hline \multicolumn{10}{|c|}{ PRODUCTION ESTIMATES } & \multirow{7}{*}{$\begin{array}{l}\text { SYSTEM } \\
\text { PERFORMANCE }\end{array}$} \\
\hline \multirow{4}{*}{\multicolumn{2}{|c|}{$\begin{array}{l}\text { ARRAY } \\
\text { Yield (unshaded) } \\
\text { Shading derate } \\
\text { Yield (shaded) }\end{array}$}} & (1) & 2 & 3 & 4 & 5 & 6 & \multicolumn{2}{|l|}{ ALL } & \\
\hline & & 1,606 & 1,478 & 1,478 & 1,478 & 1,307 & 1,606 & \multirow{2}{*}{\multicolumn{2}{|c|}{$\begin{array}{l}1,504 \mathrm{kWh} / \mathrm{kW} / \mathrm{yr} \\
88 \%\end{array}$}} & \\
\hline & & 96 & 97 & 84 & 64 & 80 & 66 & & & \\
\hline & & 1,543 & 1,438 & 1,238 & 940 & 1,036 & 1,059 & \multicolumn{2}{|c|}{$1,333 \mathrm{kWh} / \mathrm{kW} / \mathrm{yr}$} & \\
\hline \multicolumn{2}{|c|}{ Module count } & 20 & 14 & 8 & 3 & 9 & 4 & \multicolumn{2}{|c|}{58} & \\
\hline \multicolumn{2}{|l|}{ System size } & 5 & 3.5 & 2 & 0.8 & 2.3 & 1 & \multicolumn{2}{|c|}{14.5 kW STC } & \\
\hline \multicolumn{2}{|l|}{ Annual energy } & 7,717 & 5,032 & 2,477 & 705 & 2,332 & 1,059 & \multicolumn{2}{|c|}{$19,322 \mathrm{kWh}+/-10 \%$} & $\begin{array}{l}\text { Design by BrightHarvestSolar.com } \\
\text { Drawn: TR. Checked: BHS. } \\
\text { Date: 6/22/2015 }\end{array}$ \\
\hline
\end{tabular}

Figure 2: Bright Harvest Example System Performance Output 


\section{Methodology}

Measurements were taken at 43 points across four different homes in Northridge, California and the annual, summer, and winter solar access values (SAVs) from two Solmetric SunEye devices were compared to the SAVs remotely generated by Bright Harvest. The shading of the four houses varied from heavily shaded to lightly shaded and included natural and manmade obstructions. NREL collected the SunEye SAVs independently and had Bright Harvest provide calculated SAVs for identical points on the roof to NREL without knowledge of the SunEye readings for a blind study. A two one-sided statistical test (TOST) was used to compare the Bright Harvest data with the readings from the SunEye devices. In addition, NREL evaluated the differences in measured and Bright Harvest's calculations in roof tilt and azimuth using the TOST methods for over 30 roofs in New Jersey. The tables below compare the results for the mean Bright Harvest remotely calculated values to those measured on-site.

The TOST method is a test of statistical equivalence. The method can be used to determine if two data sets are statistically equivalent, i.e. if their differences fall within a given tolerance interval, for a given confidence level. A tolerance interval of \pm 5 SAVs was determined to be optimal, based on a survey in PV system installers. A confidence level of $95 \%$ was also used. Table 1 shows the results of the TOST method.

Table 1: Two One-sided Test Results - Solar Access Values

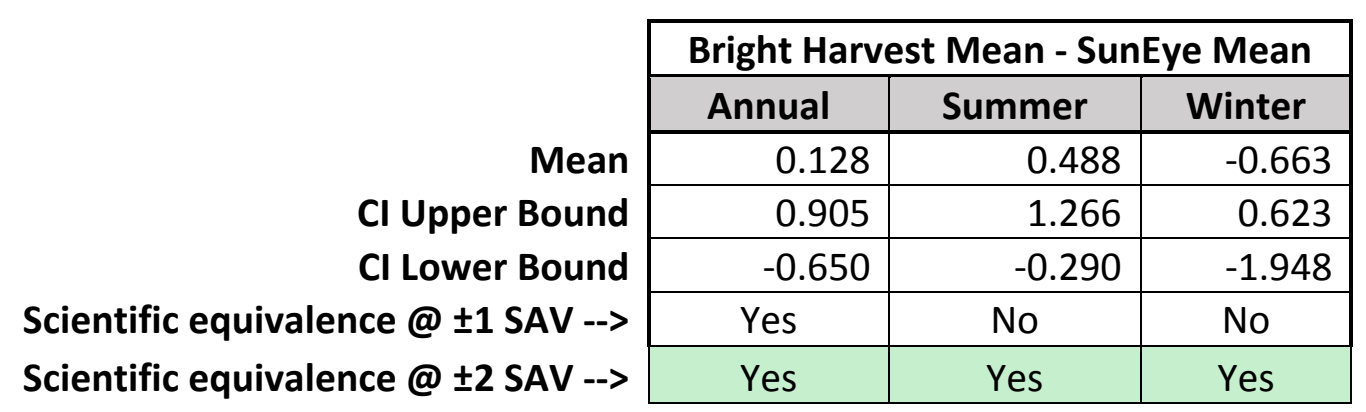

The Bright Harvest-SunEye Mean columns contain the mean difference between the Bright Harvest calculations and the SunEye measurements for the respective annual, summer and winter data sets. Since the mean differences fall within the 95\% confidence intervals (CI Upper and Lower Bound rows), and confidence intervals themselves fall within the tolerance interval of \pm 2 SAVs, the Bright Harvest calculations are statistically equivalent to the SunEye measurements within \pm 2 SAVs. This analysis is not meant to show whether or not one method of calculating SAVs is more accurate than another, but rather just shows at what level the two methods, Bright Harvest's remote assessment and on-site measurements by a Solmetric Suneye, are statistically equivalent.

A set of data with tilt angle and azimuth for 34 houses in New Jersey was used to evaluate the accuracy of Bright Harvest's method in calculating available roof area for PV panel installation. These area calculations were then used with NREL's PVWatts tool to determine panel output, in $\mathrm{W}_{\mathrm{DC}}$ for houses at each address. Tables $2-5$ below show the results of the TOST analysis for azimuth, tilt, calculated area, and estimated energy generation. 
The azimuth and tilt angle are used to describe the orientation of the PV panels, as they would be installed on a roof. Table 2 shows the TOST analysis for the azimuth and tilt angle calculations compared to the SunEye measurements taken from 33 homes located in New Jersey. As can be seen, the tilt angle estimate is equivalent to the SunEye measurement within \pm 3 degrees. For context, it is important to recognize that the difference between a 4/12 pitched roof (18.4 degrees) and 5/12 pitched roof (22.6 degrees) is just over 4 degrees. The azimuth angle estimate is even closer, within \pm 1 degree of the average SunEye measurement.

Table 2: Two One-sided Test Results - Azimuth \& Tilt

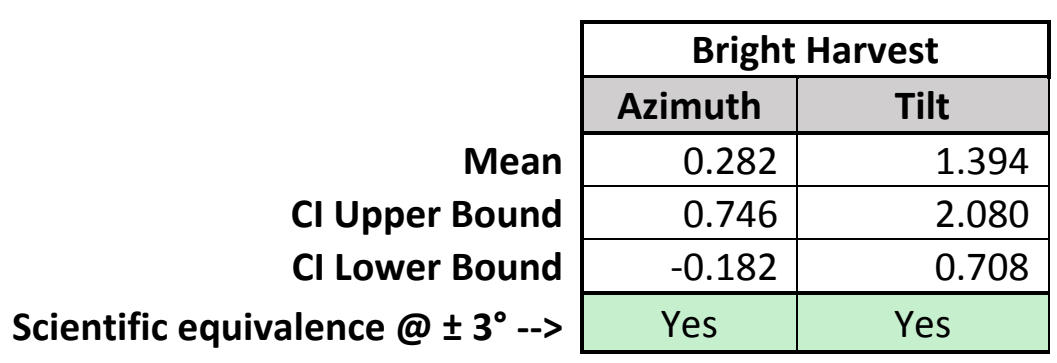

The area is calculated from the tilt angle, and is an estimate of the amount of area the PV panels would cover if they were installed on the roof being measured. Using the same New Jersey data set, the Bright Harvest estimates are equivalent to the area calculated from the measured data within $\pm 2 \%$ of the total area. Table 3 contains the TOST details.

Table 3: Two One-sided Test Results - Tilt Area

\begin{tabular}{|c|c|}
\hline \multirow{4}{*}{$\begin{array}{r}\text { Mean } \\
\text { Cunnor Round }\end{array}$} & Bright Harvest \\
\hline & Tilt Area \\
\hline & $0.99 \%$ \\
\hline & $1.56 \%$ \\
\hline $\mathrm{Cl}$ Lower Bound & $0.43 \%$ \\
\hline cientific equivalence @ $₫ 2 \%$--> & Yes \\
\hline
\end{tabular}

Finally, the tilt and azimuth are used to estimate the amount of energy produced by the proposed PV system. The energy estimates were calculated by using the calculated tilt and azimuth as an input to NREL's PVWatts tool. PVWatts then estimated the energy generation using TMY weather data for the given location. As can be seen in Table 4, the estimated energy generation using Bright Harvest remote data is within $\pm 0.5 \%$ of the energy output estimated using on-site measurements of tilt and azimuth.

Table 4: Two One-sided Test Results - Estimated Energy Generation

\begin{tabular}{|c|c|}
\hline \multirow{4}{*}{$\begin{array}{l}\text { Mean } \\
\text { Cl Unner Bound }\end{array}$} & Bright Harvest \\
\hline & Energy Generation \\
\hline & $0.17 \%$ \\
\hline & $0.38 \%$ \\
\hline Cl Lower Bound & $-0.05 \%$ \\
\hline Scientific equivalence @ $\pm 0.5 \%$--> & Yes \\
\hline
\end{tabular}




\section{Conclusions}

The analysis completed by NREL has shown a high level of scientific equivalency between the remotely-calculated values completed by Bright Harvest and on-site measurements taken by NREL for multiple residential sites in both New Jersey and California. For remote shading analysis, the Bright Harvest results are shown to be scientifically equivalent to Solmetric SunEye measurements at $\pm 2 \mathrm{SAV}$. For determining physical roof characteristics, including tilt, azimuth, and roof area, scientific equivalency was determined to exist at $\pm 3^{\circ}, \pm 1^{\circ}$, and $\pm 2 \%$ respectively.

Non-hardware (soft) costs have become a major driver of U.S. photovoltaic (PV) system prices, and aggressive soft-cost-reduction pathways must be developed to achieve the U.S. Department of Energy (DOE) SunShot Initiative's PV price targets. Upfront or "sunken" customer acquisition costs can be addressed through software solutions that aim to streamline sales and system design aspects of customer acquisition. Software solutions that automate portions of the sales and system design process can reduce overall customer acquisition costs. Through a previous study NREL has estimated the soft cost reduction potential for solutions that address the sales and system design part of the process. For software solutions including remote site assessment and improved bid prep software, savings for a residential system $(5 \mathrm{~kW})$ are estimated to be $\$ .17 / \mathrm{W}$ at scale. ${ }^{1}$ Although NREL has not independently certified the soft cost savings of the Bright Harvest products, the estimated savings of this type of tool, deployed at market scale would be generally understood to impact soft costs to a similar degree.

\footnotetext{
1 Non-Hardware (“Soft”) Cost- Reduction Roadmap for Residential and Small Commercial Solar Photovoltaics, 2013-2020, http://www.nrel.gov/docs/fy13osti/59155.pdf
} 